\title{
АДМІНІСТРАТИВНО-ПОПЕРЕДЖУВАЛЬНІ ЗАХОДИ ЗАПОБІГАННЯ ПОРУШЕННЯМ ПОРЯДКУ НАДАННЯ ФІНАНСОВИХ ПОСЛУГ У ДІЯЛЬНОСТІ НЕБАНКІВСЬКИХ ФІНАНСОВИХ УСТАНОВ
}

\author{
БУГА Ганна Сергіївна - кандидат юридичних наук, доцент, доцент кафедри \\ адміністративно-правових дисциплін факультету № 2 Донецького державного \\ університету внутрішніх справ
}

УДК 347.732

DOI 10.32782/LAW.UA.2021.4.7

\begin{abstract}
У статті під адміністративно-попереджувальними заходами запобігання порушенням порядку надання бінансових послуг у діяльності кредитних спілок в Україні запропоновано розуміти примусово-владну діяльність органів виконавчої влади та громадсъких організащій щодо бормування у правопорушників чи осіб, схильних до виинення правопорушення, законослухняної поведінки, запобігання правопорушенням, що посягають на порядок зайняття діяльністю з надання фонансових послуг, із урахуванням обставин та умов, що негативно впливають на індивідуальну протиправну поведінку особи. Виокремлено заходи попередження порушенням порядку надання фбінансових послуг у діяльності небанківсъких фінансових установ в Україні у вигляді: нормативно-правового контролю; прудениійного нагляду у бормі додержання правил надання бінансових послуг; інспектування.

Ключові слова: небанківсъка фінансова установа, бінансові послуги, правопорушення, попередження.
\end{abstract}

Механізмом правового забезпечення фінансової безпеки держави є ціла система організаційно-правових заходів впливу, що спрямована на попередження, мінімізацію та ліквідацію загроз фінансовій безпеці держави. Такий механізм є доволі складною та глибокоструктурованою системою реагування на виклики сучасності. Не винятком стала і сфера діяльності небанківських фінансових установ (НФУ).
Розширення доступу до фінансових ресурсів суб'єктів господарювання та фізичних осіб може стати одним із чинників для розвитку економіки України. Зокрема, небанківське кредитування, яке в Україні та світі розглядається як альтернатива банківському, може стати додатковим джерелом фінансування.

Характер та зміст завдань, які виконують державні органи, вимагають застосування у їх діяльності специфічних методів. Те, яким чином вони будуть виконувати поставлені державою завдання, визначатиме ступінь та якість досягнення правоохоронної мети. Тому для кращого вирішення проблем адміністративно-правового забезпечення діяльності органів у попередженні правопорушень необхідно дослідити доцільні методи їх роботи. З'ясування змісту методів діяльності цих органів дасть змогу сформулювати відповідь на питання про те, якими способами найбільш дієво та раціонально можна досягти мети їх діяльності.

До адміністративно-правових способів захисту порядку надання фінансових послуг у діяльності НФУ належать: недопущення порушення порядку надання фінансових послуг; поновлення порушеного права; притягнення до адміністративної відповідальності за вчинення правопорушення у сфері діяльності кредитних спілок; відшкодування заподіяної шкоди.

Підкреслюючи управлінський характер адміністративного примусу, слід зазначити, що застосовувати пов'язані з ним за- 
ходи правомочні не всі органи виконавчої влади і не всі їх посадові особи, а лише ті з них, кому таке право надано законодавчими актами [1, с. 35]. Адміністративний примус може бути застосовано щодо фізичних осіб, у тому числі посадових осіб, фізичних осіб - суб'єктів діяльності у сфері надання фінансових послуг. Це свідчить про індивідуалізацію його застосування. Індивідуалізація застосування також досягається через 3'ясування всіх обставин справи та вибору найбільш бажаних заходів впливу.

Адміністративному примусу як методу державного управління у сфері надання фінансових послуг притаманна специфіка юридико-фактичних підстав застосування. Основною юридично значущою підставою є протиправне діяння. Д. М. Бахрах стверджує, що примусові заходи не може бути використано поза зв'язком із конкретними правопорушеннями [2, с. 33]. Водночас застосування заходів адміністративного примусу не завжди пов'язане з адміністративним правопорушенням [3, с. 37].

Адміністративні примусові заходи у сфері порядку надання фінансових послуг у діяльності НФУ застосовують для: а) запобігання правопорушенням, недопущення настання негативних наслідків, утворення певної ситуації недопущення протиправних дій; б) переривання протиправної поведінки, припинення розпочатого або вже вчиненого протиправного діяння, що посягає на надання фінансових послуг, забезпечення провадження в справах про адміністративні проступки; в) покарання осіб, які вчинили адміністративні правопорушення.

Ю. П. Битяк визначає адміністративний примус як систему засобів психологічного або фізичного впливу на свідомість і поведінку людей 3 метою досягнення чіткого виконання встановлених обов'язків, розвитку суспільних відносин у межах закону, забезпечення правопорядку й законності [4, с. 169-170]. Натомість Г. П. Бондаренко зазначає, що адміністративний примус - це складова державного примусу, що полягає в застосуванні органами державного управління, судами та суддями, службовими особами, а у встановлених законодавством випадках - громадськістю в межах, формах і порядку, регламентованих чинним законодавством, державно-правового, психологічного та фізичного впливу до правопорушників $з$ метою захисту охоронюваних правом конкретних суспільних відносин [5, с. 21].

Характеризуючи види адміністративного примусу, слід зазначити, що немає єдиного погляду щодо цього питання. У теорії адміністративного права існує декілька класифікацій заходів адміністративного примусу. Так, О. М. Бандурка, Ю. П. Битяк, С. Т. Гончарук, С. В. Ківалов, А. Т. Комзюк підтримують запропоновану М. I. Еропкіним класифікацію заходів адміністративного примусу на заходи адміністративного запобігання, заходи адміністративного припинення та заходи адміністративного стягнення [6, с. 105]. Проте не всі науковці погоджуються з такою класифікацією. Наприклад, Д. М. Бахрах заперечує існування такого виду адміністративного примусу, як заходи адміністративного запобігання, вважаючи, що адміністративний примус застосовують тоді, коли наявне адміністративне правопорушення. Науковець виокремлює такий вид адміністративного примусу, як відновлювальні заходи [4, с. 236]. Досліджуючи означену тематику, С. С. Студенікін поділяе всі адміністративно-примусові заходи залежно від наявності адміністративно-правової санкції на адміністративні стягнення та інші заходи примусу (заходи адміністративного забезпечення, адміністративно-правові заходи соціального примусу або заходи припинення) [8, с. 172-174].

Враховуючи предмет розгляду у статті, варто розподілити заходи адміністративного примусу у сфері надання фінансових послуг у діяльності НФУ на: заходи адміністративного попередження (запобігання), заходи адміністративного припинення, адміністративні стягнення.

Заходи адміністративного попередження мають на меті не дати здійснитися протиправному вчинку. Їх застосовують у випадку, якщо правопорушення лише передбачаються, тобто вони не пов'язані зі здійсненням правопорушень. Вони їм запобігають i, у цьому контексті, передують застосуванню інших примусових заходів, спрямованих проти винних у здійсненні 


\section{Адміністративне право}

адміністративних правопорушень. Ці заходи часто називають адміністративно-запобіжними, адміністративно-попереджувальними. Їх застосовують різні суб'єкти 3 компетенцією контрольно-наглядового характеру з метою попередження правопорушення в різних сферах громадського життя. Вони здебільшого мають галузевий (відомчий) профіль, але можуть здійснюватися й органами із загальною управлінською компетенцією [9, с. 184; 10, с. 59; 11 , c. $311 ; 12$, с. 130].

Сутність попередження порушень надання фінансових послуг у діяльності кредитних спілок полягає у недопущенні протиправної поведінки з боку конкретних осіб, які до такої поведінки схильні, в усуненні причин, що сприяють вчиненню таких порушень та створення умов, що виключають протиправну поведінку. Подруге, в усуненні причин, що зумовлюють учинення правопорушень і створення умов, які унеможливлюють протиправну поведінку. Адміністративно-попереджувальні заходи запобігання у сфері надання фінансових послуг наділені певними особливостями: виявляються у вигляді контролю та нагляду за діяльністю, обмежень та заборон, що свідчить про їх примусову природу; незважаючи на те, що ці заходи є попереджувальними, вони здійснюються в односторонньому примусовому порядку органами і посадовими особами, які наділені владними повноваженнями у сфері надання фінансових послуг [13, с. 22].

Слід погодитися 3 Ю. П. Битяком [14, c. 152-153] стосовно того, що, попри чітко виражений профілактичний характер, такі заходи здійснюють у примусовому порядку, тобто в процесі однобічної реалізації владних повноважень, а отже, безпідставними є спроби представити їх як заходи, позбавлені елементів адміністративного примусу. Вони зазвичай мають вигляд обмежень і заборон, що досить показово характеризує їхню примусову природу.

Законодавець розцінює адміністративно-попереджувальну роботу як важливий компонент забезпечення законності, порядку й дисципліни. 3 огляду на це, він вводить до КУпАП спеціальну статтю (ст. 6
«Попередження адміністративних правопорушень») [15], яка передбачає здійснення профілактичних заходів, визначає їх цілі та суб'єкти [12, с. 131].

На відміну від заходів адміністративного припинення, які безпосередньо переривають явні правопорушення або об'єктивно протиправні діяння, створюють умови для подальшого вжиття відносно порушника заходів відповідальності адміністративного чи іншого характеру, адміністративно-попереджувальні заходи не переривають безпосередньо правопорушення, а спрямовані на його попередження та відвернення. Від адміністративних стягнень адміністративно-попереджувальні заходи, не маючи карального характеру, не потребують встановлення вини порушення як обов'язкової умови застосування [16, с. 85].

Необхідно підкреслити ще одну важливу особливість адміністративно-попереджувальних заходів. Суть іiі полягає в тому, що адміністративно-запобіжні заходи мають багато спільного із заходами адміністративного припинення. Це стосується здебільшого забезпечення можливості притягнення правопорушників до адміністративної чи кримінальної відповідальності. Так, огляд речей і особистий огляд можуть застосовуватися як адміністративно-запобіжні заходи та як заходи, спрямовані на припинення протиправного діяння, забезпечення можливості притягнення правопорушника до адміністративної, іноді й до кримінальної відповідальності (тобто як заходи адміністративного припинення). Попри те, що питання про віднесення огляду до певного виду примусу має більш теоретичне, ніж практичне значення, неможливо не помітити практичної значущості зазначеної проблеми, оскільки порядок здійснення огляду врегульовано низкою законів України, а його застосування переслідуе різну мету [16, с. 91].

На нашу думку, адміністративно-попереджувальні заходи запобігання порушенням порядку надання бінансових послуг у діяльності НФУ в Україні слід визначити як примусово-владну діяльність органів виконавчої влади та громадсъких організацій щьоо бормування у правопорушників чи осіб, схильних до вчинен- 
ня правопорушення, законослухняної поведінки, запобігання правопорушенням, що посягають на порядок зайняття діяльністю з надання бінансових послуг, з урахуванням обставин та умов, що негативно впливають на індивідуальну протиправну поведінку особи.

Адміністративно-попереджувальні заходи запобігання у сфері надання фінансових послуг наділені певними особливостями: виявляються у вигляді контролю й нагляду за діяльністю, обмежень і заборон, що свідчить про їх примусову природу; незважаючи на те, що ці заходи є попереджувальними, вони здійснюються в односторонньому примусовому порядку органами та посадовими особами, які наділені владними повноваженнями у сфері надання фінансових послуг.

До загальних способів попередження правопорушень Ю. П. Битяк зараховує способи: виховного характеру, контролю та нагляду, звернення громадян і примусу [4, с. 217]. Виховний ефект досягається шляхом застосування органами державної влади виховного впливу до небанківських фінансових установ, зокрема кредитних спілок.

Відповідно до ст. 21 Закону України «Про фінансові послуги та державне регулювання ринків фінансових послуг» [17], Нацкомфінпослуг здійснює державне регулювання порядку надання фінансових послуг у діяльності кредитних спілок в Україні.

Адміністративно-попереджувальні заходи запобігання порушенням порядку надання фінансових послуг у діяльності кредитних спілок в Україні Начкомбінпослуг здійснюе шляхом: 1) нормативно-правового контролю за діяльністю кредитних спілок; 2) пруденційного нагляду у бормі додержання правил надання фбінансових послуг; 3) інспектування.

Основні напрями попередження порушень надання фінансових послуг у сфері діяльності НФУ здійснюються шляхом: запровадження елементів пруденційного нагляду, перегляд фінансових нормативів діяльності кредитних установ; спрощення дозвільних процедур розгляду документів шляхом запровадження процедури одночасного прийняття рішень НБУ щодо внесення інформації про заявника до Держав- ного реєстру фінансових установ та видачі йому ліцензії, а також єдиного пакета документів, який подається заявникам для прийняття цих рішень; використання розробленого порядку удосконалення: умов і механізмів ліцензування 3 надання фінансових послуг; подання річної фінансової звітності та аудиторського висновку до НБУ; формування звітних даних кредитними установами; розкриття інформації про фінансову діяльність.

НБУ під час прийняття рішень про застосування заходів впливу у випадку порушення законодавства про фінансові послуги/законодавства про захист прав споживачів у межах своїх повноважень застосовує до: страховиків; кредитних спілок; небанківських фінансових установ, інших, ніж страховики, кредитні спілки, установи-кредитодавці, установи - нові кредитори, установи - колекторські компанії; небанківських фінансових груп; осіб, які не є фінансовими установами; осіб, що надають посередницькі послуги на ринках фінансових послуг; установ-кредитодавців (крім кредитних спілок), установ-нових кредиторів; установ-колекторських компаній; фізичних осіб-підприємців; філій страховиків-нерезидентів [18].

НБУ у межах своїх повноважень у сфері державного регулювання ринків небанківських фінансових послуг має право застосовувати такі заходи впливу:

1) зобов'язати порушника вжити заходів для усунення порушення та/або вжити заходів для усунення причин, що сприяли вчиненню порушення;

2) вимагати скликання позачергових зборів учасників фінансової установи;

3) накладати штрафи;

4) тимчасово зупиняти або відкликати (анульовувати) ліцензію на провадження діяльності з надання фінансових послуг;

5) відсторонювати керівництво від управління фінансовою установою та призначати тимчасову адміністрацію;

6) затверджувати план відновлення фінансової стабільності фінансової установи;

7) виключати відповідно до законодавства учасників ринків фінансових послуг (крім клієнтів) 3 Державного реєстру $ф і-$ 
нансових установ або реєстру осіб, які не $\epsilon$ фінансовими установами, але мають право надавати окремі фінансові послуги;

8) укладати письмову угоду 3 фінансовою установою, особою, яка не є фінансовою установою, але має право надавати окремі фінансові послуги, за якою така особа зобов'язується сплатити визначене грошове зобов'язання та/або вжити заходів для усунення та/або недопущення в подальшій діяльності порушень, поліпшення фінансового стану фінансової установи, підвищення ефективності функціонування системи управління ризиками тощо;

9) невиконання або неналежне виконання фінансовою установою, особою, яка не є фінансовою установою, але має право надавати окремі фінансові послуги, умов письмової угоди;

10) установлювати для небанківських фінансових груп підвищені економічні нормативи, ліміти та обмеження щодо здійснення окремих видів операцій.

НБУ за порушення в діяльності відокремленого підрозділу учасника ринку небанківських фінансових послуг застосовує такі заходи впливу і до юридичної особи учасника ринку небанківських фінансових послуг (крім філій страховиків-нерезидентів) [17].

Таким чином, підводячи підсумки статті, зазначимо, що серед заходів адміністративного примусу одними 3 найпоширеніших $є$ адміністративно-запобіжні заходи, які застосовуються уповноваженими органами державної влади. Адміністративно-запобіжні заходи передбачають у встановлених законом випадках застосування обмежень до НФУ і в цьому виявляється їх примусовий характер, хоча правопорушення при цьому відсутні. Ось чому ці заходи мають чітку профілактичну спрямованість, мають за мету захистити інтереси фінансової безпеки, не допустити вчинення правопорушень.

Адміністративно-попереджувальним заходам запобігання властиві певні особливості, які характеризують їх місце в єдиній системі заходів адміністративного примусу. Суть цих особливостей полягає в тому, що адміністративно-попереджувальні заходи тісно пов'язані із заходами припинення i заходами стягнення. Зв’язок адміністративно-попереджувальних запобіжних заходів із заходами адміністративного припинення виявляється, перш за все, у тому, що вони в багатьох випадках є попередниками заходів адміністративного припинення. У той же час застосування заходів припинення часто передує застосуванню адміністративних стягнень, оскільки забезпечує можливість притягнення правопорушника до адміністративної відповідальності.

Разом 3 тим адміністративно-попереджувальні запобіжні заходи у сфері фінансової безпеки виконують свої особливі охоронні функції, які відрізняють їх від інших заходів адміністративного примусу, що і визначає їх самостійне місце в системі цих заходів. Наприклад, застосування заходів адміністративного припинення характеризується тим, що воно викликається реальною протиправною (у тому числі об'єктивно протиправною) ситуацією і починається в момент, коли ця ситуація досягла певного розвитку, коли використання запобіжних заходів стає вже неефективним або й зовсім непотрібним. На відміну від заходів адміністративного припинення, які безпосередньо переривають явні правопорушення або об'єктивно протиправні діяння, створюють умови для встановлення особи порушника, з'ясування обставин справи і реальної можливості для подальшого застосування до порушника заходів відповідальності адміністративного чи іншого характеру, адміністративно-запобіжні заходи не переривають безпосередньо правопорушення, а попереджують, відвертають його вчинення.

На відміну від адміністративних стягнень адміністративно-попереджувальні заходи не містять у собі функції покарання до фізичних осіб НФУ або до самої НФУ, до якої вони застосовуються. Адміністративно-попереджувальні заходи, не маючи карального характеру, не потребують встановлення вини порушника як обов'язкової умови застосування.

Необхідно підкреслити і ще одну важливу особливість адміністративно-попереджувальних заходів запобігання порушенням порядку надання фінансових послуг у 
діяльності небанківських фінансових установ, суть якої полягає в тому, що такі заходи мають багато спільного із заходами адміністративного припинення. В основному це стосується забезпечення можливості притягнення правопорушників до адміністративної чи кримінальної відповідальності. Так, огляд документації може застосовуватися як адміністративно-попереджувальний захід і як захід, спрямований на припинення протиправного діяння, забезпечення можливості для вирішення питання про притягнення уповноважених осіб НФУ до адміністративної або кримінальної відповідальності (тобто як заходи адміністративного припинення). Однак питання про віднесення огляду до того чи іншого виду адміністративного примусу має більше теоретичне, ніж практичне значення. Однак не можна не помітити практичної значущості зазначеної проблеми, оскільки використання огляду регулюється цілою низкою законів України, а його застосування переслідує різну мету.

\section{入iтература}

1. Остапенко О. I., Остапенко Л. О. Адміністративно-правове забезпечення захисту права власності в Україні : навч. посіб. Аьвів, 2007. 149 с.

2. Бахрах Д. Н. Состав административного проступка : учеб. пособие. Свердловск, 1987. 70 с.

3. Личенко I. О. Адміністративно-деліктні аспекти захисту права власності : монографія. Аьвів, 2011. 216 с.

4. Битяк Ю. П. Адміністративне право України : підручник. Харків, 2001. 528 с.

5. Бондаренко Г. П. Адміністративна відповідальність в СРСР. Аьвів, 1975. 176 с.

6. Коломоєць Т. Класифікація заходів адміністративно-правового примусу. Право України. 2003. № 2. С. 105-111.

7. Бахрах Д. Н. Административное право : учебник. М., 2000. 624 с.

8. Студеникин C. C. Советское административное право. М., 1950. 340 с.

9. Стеценко С. Г. Адміністративне право України : навч. посіб. Київ, 2007. 624 с.
10. Коломоєць Т. О., Аютіков П. С., Меліхова О. Ю. Адміністративне право України : підручник. Київ, 2012. 528 с.

11. Воронова $\mathcal{\lambda}$. К. Фінансове право України : підручник. Київ, 2006. 448 с.

12. Прокопенко В. В. Заходи адміністративного припинення, які застосовуються митними органами. Митна справа. 2012. № 4. С. 125-137.

13. Гончарук С. Т. Адміністративна відповідальність за законодавством України: адміністративно-юрисдикційні повноваження ОВС : навч. посіб. Київ, 1995. 78 с.

14. Адміністративне право України : підруч. / [Ю. П. Битяк, В. М. Гаращук,О. В. Дьяченко та ін.]. Київ, 2005. 544 с.

15. Кодекс України про адміністративні правопорушення : Закон України від 7 груд. 1984 р. № 8073-X. URL: http:// zakon3.rada.gov.ua/laws/show/80731-10.

16. Комзюк А. Т. Адміністративний примус в правоохоронній діяльності міліції в Україні : дис. ... докт. юрид. наук : 12.00.07. Харків, 2002. 408 с.

17. Про фінансові послуги та державне регулювання ринків фінансових послуг : Закон України від 12 лип. 2001 р. № 2664III. URL: http://zakon2.rada.gov.ua/laws/ show/2664-14.

18. Про затвердження Положення про застосування Національним банком України заходів впливу у сфері державного регулювання діяльності на ринках небанківських фінансових послуг : постанова Правління Національного банку України від-1 лют. 2021 р. № 12. Верховна Рада Украӥни. URL: https://zakon.rada.gov.ua/laws/show/ v0012500-21 \#Text.

\section{ADMINISTRATIVE AND PREVENTIVE MEASURES VIOLATION OF THE PROCEDURE FOR PROVIDING FINANCIAL SERVICES IN THE ACTIVITY NON-BANK FINANGIAL INSTITUTIONS \\ The article emphasizes that among the measures of administrative coercion, one of the most common are administrative pre- cautionary measures applied by authorized state authorities. Administrative precaution- ary measures provide for the application of}




\section{Адміністративне право}

\section{АНОТАЦІЯ}

У статті наголошено, що серед заходів адміністративного примусу одними з найпоширеніших $\epsilon$ адміністративно-запобіжні заходи, які застосовуються уповноваженими органами державної влади. Адміністративно-запобіжні заходи передбачають у встановлених законом випадках застосування обмежень до небанківських ббінансових установ $і$ в извому виявляеться їх примусовий характер, хоча правопорушення при изому відсутні. Ось чому чі заходи мають чітку пробілактичну спрямованість, мають за мету захистити інтереси ббінансової безпеки, не допустити вчинення правопорушень.

Адміністративно-попереджувальним заходам запобігання властиві певні особливості, які характеризують їх місие в єдиній системі заходів адміністративного примусу. Суть изх особливостей полягає в тому, що адміністративно-попереджувальні заходи тісно пов'язані із заходами припинення $і$ заходами стягнення. Зв'язок адміністративно-попереджувальних запобіжних заходів із заходами адміністративного припинення виявляється, пери за все, у тому, що вони в багатьох випадках є попередниками заходів адміністративного припинення. У той же час застосування заходів припинення часто передує застосуванню адміністративних стягнень, оскільки забезпечує можливість притягнення правопорушника до адміністративної відповідальності.

y статті під адміністративно-попереджувальними заходами запобігання порушенням порядку надання фінансових послуг у діяльності кредитних спілок в Украӥні запропоновано розуміти примусово-владну діяльність органів виконавчої влади та громадських організащій щодо бормування у правопорушників чи осіб, схильних до вчинення правопорушення, законослухняної поведінки, запобігання правопорушенням, що посягають на порядок зайняття діяльністю з надання бінансових послуг, із урахуванням обставин та умов, що негативно впливають на індивідуальну протиправну поведінку особи. Виокремлено заходи попередження порушенням порядку надання бінансових послуг у діяльності небанківсъких фбінансових установ в Украӥні у вигляді: нормативно-правового контролю; прудениійного нагляду у формі додержання правил надання фінансових послуг; інспектування.

Ключові слова: небанківська бінансова установа, бонансові послуги, правопорушення, попередження. restrictions on non-bank financial institutions in cases established by law, and this reveals their coercive nature, although there are no offenses. That is why these measures have a clear preventive focus, are aimed at protecting the interests of financial security, to prevent offenses.

Administrative-preventive measures are characterized by certain features that characterize their place in a single system of administrative coercion. The essence of these features is that administrative and preventive measures are closely related to measures of suspension and recovery measures. The connection between administrative precautionary measures and administrative termination measures is manifested, first of all, in the fact that in many cases they are precursors of administrative termination measures. At the same time, the application of termination measures often precedes the application of administrative penalties, as it provides an opportunity to bring the offender to administrative responsibility.

In the article, administrative and preventive measures to prevent violations of the procedure for providing financial services in the activities of credit unions in Ukraine are proposed to understand the coercive activities of executive authorities and public organizations to form offenders or persons prone to crime, law-abiding behavior, crime prevention. encroach on the procedure for engaging in financial services, taking into account the circumstances and conditions that adversely affect the individual illegal behavior of the person. Measures to prevent violations of the procedure for providing financial services in the activities of non-bank financial institutions in Ukraine in the form of: regulatory and legal control; prudential supervision in the form of compliance with the rules of financial services; inspection.

Keywords: non-bank financial institution, financial services, offenses, warnings. 